\title{
ACTIVITY OF SUPEROXIDE DISMUTASE AND CATALASE IN THE GASTRIC MUCOSA OF RATS UNDER THE PROLONGED ADMINISTRATION OF OMEPRAZOL AND COMBINATION OF OMEPRAZOLE AND MULTIPROBIOTICS
}

DOI:10.36740/WLek202102127

\author{
Serhii V. Pylypenko, Andrii A. Koval, Viktoria V. Makarchuk \\ UKRAINIAN POLTAVA V.G. KOROLENKO NATIONAL PEDAGOGICAL UNIVERSITY, POLTAVA, UKRAINE
}

\begin{abstract}
The aim: Of the study was to study the activity of superoxide dismutase and catalase in the gastric mucosa of rats under long-term administration of omeprazole and combined administration of omeprazole with Symbiter and Apibact multiprobiotics.

Materials and methods: The study was carried out on 40 white non-linear male rats with an initial weight of $160-180 \mathrm{~g}$. All animals were divided into $4 \mathrm{groups}$. Group I was the control. Group II was administered omeprazole once a day within the period of 28 days. Group III was administered a combination of omeprazole and Symbiter ${ }^{\circledast}$ multiprobiotic. Group IV was administered a combination of omeprazole and Apibact ${ }^{\oplus}$ multiprobiotic.

The activity of superoxide dismutase in cells was determined by Chevars et al. . The catalase activity in cells was determined by Korolyuk et al. . Statistical processing of the results was performed using the "Statistica 7.0 " software.

Results: The activity of SOD and catalase in the gastric mucosa of rats after 28 days of omeprazole administration increased compared to the control. Probiotics reduced the activity of SOD compared to the group of rats where omeprazole only was administered. The catalase activity in the gastric mucosa of rats which were jointly administered omeprazole and multiprobiotics for 28 days did not statistically significantly differ from the similar index in the control group.

Conclusions: Prolonged gastric juice hypochlorhydria led to depletion of antioxidant protection enzymes. Multiprobiotics reduced the manifestation of the inflammatory process in the gastric mucosa.
\end{abstract}

KEY WORDS: hypochlorhydria, proton pump blockers, inflammatory process

Wiad Lek. 2021;74(2):317-320

\section{INTRODUCTION}

A special feature of many digestive tract organs' diseases is their recurrent nature, as well as their treatment failure in a number of diseases and impossibility to achieve complete clinical remission. Thus, in chronic stomach erosions only half of cases manage to achieve a complete recovery [1]. As for atrophic gastritis with hypo- or anacidity of gastric juice, the picture is even worse. After all, the loss of parietal cells is irreversible, so the treatment of such gastritis is symptomatic and aimed at stopping the disease progression. The use of drugs with antioxidant properties will prevent the pathological process development, as it is noted in the literature [2].

We studied the digestive tract motility functioning under the conditions of prolonged hypacidity of gastric juice and showed the development of inflammatory process in the mucous membrane of the stomach, which led to the suppression of spontaneous and stimulated contractile activity in it. Significant restoration of the stomach motility against the background of omeprazole and multiprobiotics simultaneous administration led us to study the mechanism of the revealed phenomenon [3].

\section{THE AIM}

The aim of our work was to study the activity of superoxide dismutase and catalase in the mucous membrane of the stomach in rats under long-term administration of omeprazole and combined administration of omeprazole and multiprobiotics Symbiter and Apibakt.

\section{MATERIALS AND METHODS}

The study was carried out on 40 white non-linear male rats with an initial weight of 160-180 g which were kept in the accredited vivarium of the Educational and Scientific Center "Institute of Biology" at Taras Shevchenko National University of Kyiv in compliance with the "Standard rules for the ordering, equipping and maintenance of experimental biological clinics (vivariums) ". All experiments were carried out in compliance with the Law of Ukraine No. 3447-IV "On the Protection of Animals from Cruel Treatment".

All animals were divided into 4 experimental groups. Group 1 of animals served as a control. They were administered intraperitoneally (i/p) $0.2 \mathrm{ml}$ and orally (p/o) 
$0.5 \mathrm{ml}$ of water for injection within 28 days. Animals of group 2 received omeprazole and $0.5 \mathrm{ml}$ of water for injection once a day for 28 days. Animals of group 3 were co-administered omeprazole and Symbiter ${ }^{\bullet}$ acidophilic concentrated (Simbiter) multi-probiotic once a day for 28 days. Animals of group 4 were administered omeprazole and Apibact ${ }^{\oplus}$ (Apibact) multibiotic simultaneously once a day within 28 days.

Omeprazole (manufactured by "Sigma-Aldrich", USA) was injected intravenously in a dose of $14 \mathrm{mg} / \mathrm{kg}$, dissolved in $0.2 \mathrm{ml}$ of water for injection. Multiprobiotics Simbiter and Apibact (manufactured by OD Prolisok, Ukraine) were administered in combination with omeprazole $\mathrm{p} / \mathrm{o}$ at a dose of $140 \mathrm{mg} / \mathrm{kg}\left(1.4^{\star} 1010 \mathrm{CFU} / \mathrm{kg}\right)$. Multiprobiotics were dissolved in $0.5 \mathrm{ml}$ of water for injection.

The activity of superoxide dismutase (KF 1.15.1.1) in cells was determined by Chevars et al. [4]. The method is based on the ability of superoxide dismutase to compete with nitro blue tetrazolium (NBT) for superoxide anions formed as a result of aerobic interaction of the reduced form of nicotinamidadienedin dinucleotide and phenazine methasulphate (PMS). As a result of this reaction, NBT is restored with the formation of hydrazine tetrazolium. In the presence of superoxide dismutase, the percentage of NBT recovery is reduced.

In a sample containing $0.15 \mathrm{M}$ phosphate buffer, an aliquot of blood serum, cell lysate or mucous membranes homogenate $(0.5 \mathrm{mg}$ of protein) was added, the total volume of the test was $0.5 \mathrm{ml}$. To the sample $1 \mathrm{ml}$ of reagent I was added $(57 \mu \mathrm{M}$ NST, $16 \mu \mathrm{M}$ FMS to $0.15 \mathrm{M}$ phosphate buffer with EDTA, $\mathrm{pH}=7.8$ ). Immediately, absorbance of samples was measured at $\lambda=540 \mathrm{~nm}$ with a spectrophotometer (SF-46, LOMO, Russia). Then, $0.035 \mathrm{ml}$ of reagent II ( $98.5 \mu \mathrm{M}$ NAD.H with Tris-EDTA buffer, $\mathrm{pH}=8.0)$ was added to each sample, put in the dark place, and the extinction was re-determined in 10 minutes under the same conditions. Samples were kept at $30^{\circ} \mathrm{C}$. The formula was used to calculate the percentage of NBT recovery degree inhibition in the sample:

$\mathrm{E}=\Delta$ Ezero $\times 50$, where:

$\Delta$ Estud $\mathrm{x} 100 \mathrm{x} \mathrm{t} \times \mathrm{a}$

$\mathrm{E}$ - superoxide dismutase activity;

$\Delta$ Ezero - sample extinction before reagent II adding;

$\Delta$ Estud - sample extinction after reagent II adding;

$50 / 100-50 \%$ blocking of NBT recovery reaction;

a -protein content in the sample, mg;

$\mathrm{t}$-incubation period $10 \mathrm{~min}$.

The enzyme activity was expressed in standard units per minute per $1 \mathrm{mg}$ of protein.

The catalase (KF 1.11.1.6) activity in cells was determined by Korolyuk et al. [5]. The principle of the method lies in the fact that catalase destroys the substrate $\mathrm{H}_{2} \mathrm{O}_{2}$, the undamaged part of hydrogen peroxide, when in contact with molybdenum salts, forms a stable colored complex.

In a test tube, $2 \mathrm{ml}$ of a $0.03 \%$ solution of hydrogen peroxide was added. The reaction was started by adding 0.1 $\mathrm{ml}$ of blood serum, cell lysate or mucosal homogenate ( 0.1 $\mathrm{mg}$ of protein). In the control sample, instead of protein,
$0.1 \mathrm{ml}$ of distilled water was added. Samples were kept at room temperature for $10 \mathrm{~min}$, the reaction was stopped by adding of $1 \mathrm{ml}$ of $4 \%$ ammonium molybdate. The coloration intensity was measured with a spectrophotometer (SF-46, LOMO, Russia) at $\lambda=410 \mathrm{~nm}$ against a control sample, in which, instead of hydrogen peroxide, $2 \mathrm{ml}$ of $\mathrm{H}_{2} \mathrm{O}$ was added.

The catalase activity was calculated according to the formula:

$\mathrm{E}=($ Acontr - Astud $)$, where:

$\mathrm{K} x \mathrm{tx}$ a

E - catalase activity;

Acontr i Astud - control and studied samples' extinction;

$\mathrm{K}$ - millimolar extinction factor of hydrogen peroxide, which equals $22.2 \times 103 \mathrm{MM}-1 \times \mathrm{cm}-1$;

$\mathrm{t}$ - incubation period $10 \mathrm{~min}$;

$\mathrm{a}$ - protein content in the sample, $\mathrm{mg}$.

The activity was measured in $\mathrm{nM} \mathrm{H}_{2} \mathrm{O}_{2}$ in 1 min per 1 mg of protein.

Statistical processing of the results was performed using the Statistica 7.0 software. Since the obtained data were normally distributed, we determined the mean $(\mathrm{M})$ and the standard error of the mean $(\mathrm{m})$ and compared the samples by means of the Student's t-criterion.

\section{RESULTS}

Significant changes in the activity of antioxidant enzymes in the rat stomach mucosa after prolonged administration of omeprazole were observed.

The activity of SOD and catalase in the rat mucous membrane after 28 days of omeprazole administration increased by $446.7 \%(\mathrm{p}<0.001)$ and $26.3 \%(\mathrm{p}<0.05)$, respectively, compared to the control (fig. 1A, 1B).

In the mucous membrane of the stomach in rats, which were administered omeprazole and Symbiter ${ }^{\circledR}$ multiprobiotic and omeprazole and Apibact ${ }^{\circ}$ multiprobiotic in combination, the activity of SOD reduced by $57 . \%(\mathrm{p}<0.05)$ and $34.1 \%(\mathrm{p}<0.01)$ over the course of 28 days, compared to the group of rats, which were administered omeprazole only (fig. 1A). However, it remained above this index in the control. The activity of SOD under the conditions of of omeprazole and Symbiter multiprobiotik combined administration was $146.7 \%$ ( $\mathrm{p}<0.05)$, while under the conditions of omeprazole and Apibact multiprobiotik combined administration $260 \%(\mathrm{p}<0.05)$ it was higher compared to the control.

The catalase activity in the mucous membrane of the rat stomach, which was administered with omeprazole and multiprobiotics in combination within 28 days, was not statistically reliably different from that of the studied index in the control (fig. 1B).

\section{DISCUSSION}

The data we obtained earlier on the significant increase in the content of TBA-reactive substances and NO products is the evidence of oxidative / nitrosative stress development 


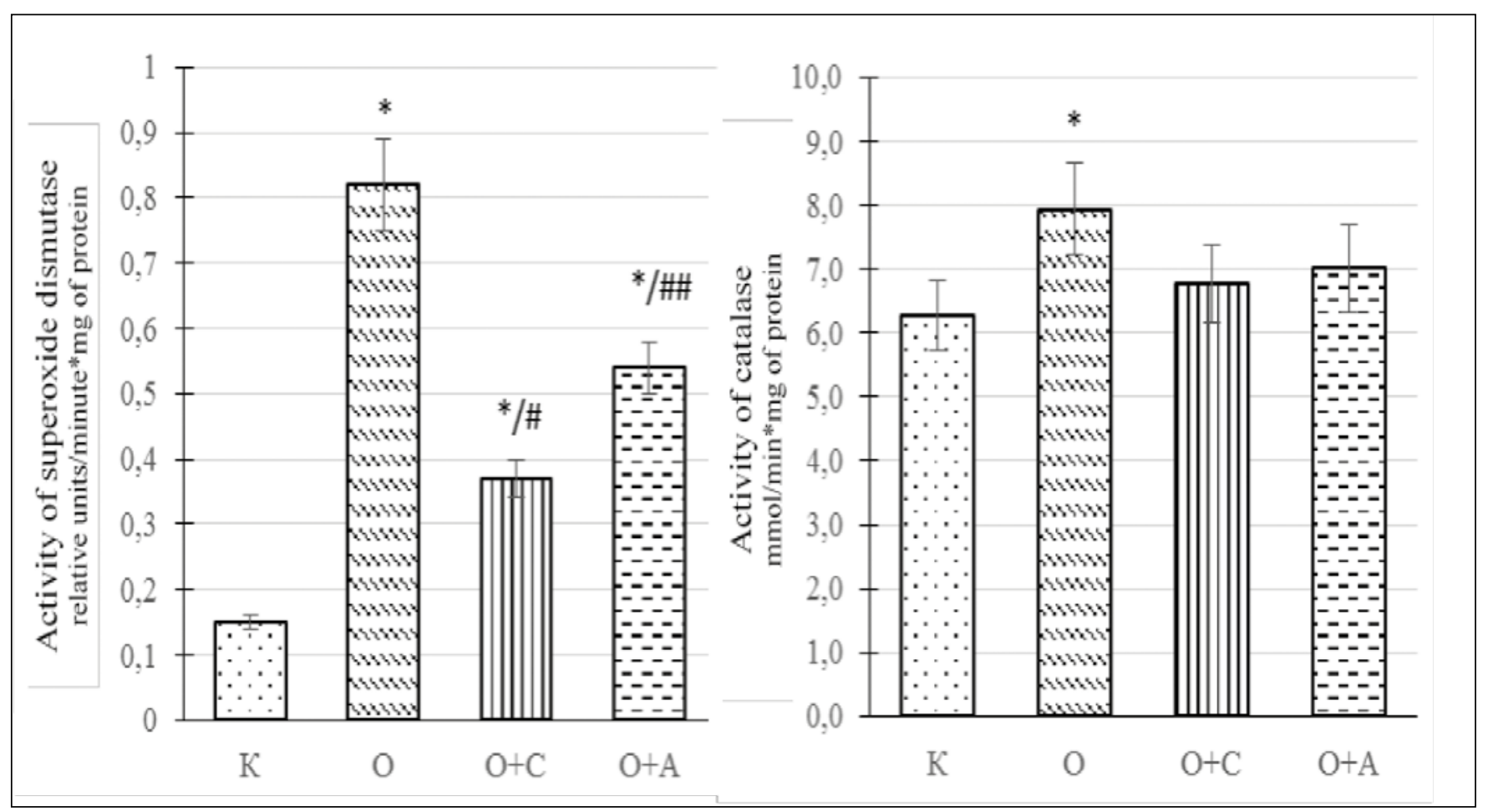

Fig. 1. Activity of superoxide dismutase $(A)$ and catalase $(B)$ in the mucous membrane of the rat stomach, $(M+m)$ :

$K$ - control group $(n=10) ; 0$-group of rats after 28-days of omeprazole administration $(n=10) ; 0+C$ - group of rats after 28-days of the combined omeprazole and Symbiter ${ }^{\oplus}$ multiprobiotic administration $(n=10) ; 0+A$ - group of rats after 28-days of the combined omeprazole and Apibact ${ }^{\ominus}$ multiprobiotic administration $(\mathrm{n}=10)$;

$*-p<0.05$ compared to the control;

$\#-p<0.05, \#-p<0.05$ compared to the group of rats after omeprazole administration.

in the mucous membrane of the stomach under prolonged gastric hypochlorohydria [1].

After 28 days of $\mathrm{HCl}$ secretion inhibition, we observed an increase in the activity of superoxide dismutase in the gastric mucous membrane, indicating a significant intensity of the inflammatory process in the stomach, oxidative / nitrosative stress is the result of an imbalance in the antioxidant support system.

Significant increase in the SOD activity was the result of an increase in the formation of oxygen active forms due to stimulation of cytokines by TNF- $\alpha$, IL- $1 \beta$ and INF- $\gamma$ [6], which, according to our data, grew after 28 days of omeprazole administration $[6,7]$.

The inflammatory process is the result of dysbiotic changes in the stomach, which is normally weakly inhabited by microorganisms, and the proximity of target cells (ECL cells and parietal cells) to gastrin and its long hypersecretion.

Under these conditions, an excessive amount of hydrogen peroxide may accumulate in the mucous membrane of the stomach, as the catalase activity that restores it was growing insignificantly.

Our data on the antioxidant properties of multiprobiotics are confirmed by other authors who report the ability of different lactic acid bacteria strains to suppress the lipid peroxidation (LPO) processes and to capture and neutralize free radicals $[7,8]$. In addition, it has been shown that Api- bact ${ }^{\oplus}$ multiprobiotic reduces the LPO products content in the pancreas and liver of rats under the conditions of prolonged gastric juice hypoacidity caused by omeprazole [9].

\section{CONCLUSIONS}

1. Prolonged hypochlorhydria of gastric juice resulted in changes in the functioning and exhaustion of antioxidant support enzymes: compared to the control, the activity of SOD and catalase in the stomach mucous membrane increased by $446.7 \%(\mathrm{p}<0.001)$ and by $26.3 \%(\mathrm{p}<0.05)$.

2. Prolonged administration of multiprobiotic drugs against the background of gastric hypochlorohydria significantly reduced the manifestation of inflammatory process in the stomach mucous membrane, which manifested itself in normalization of antioxidant system enzymes activity.

\section{REFERENCES}

1. Pylypenko S.V., Koval A.A., MakarchukV.V. Impact of multiprobiotics on the content of TBA-reactive substances in the blood serum and mucous membranes of the stomach and colon in rats with long-term gastric hypochlorhydria. World of medicine and biology. 2018;3(65):218-222. doi:10.26724/2079-8334-2018-3-65-218-222

2. Horchakova N.O., Oliynyk S.A., Harkava K.H. Antyoksydantni zasoby neobkhidni komponenty kompleksnoyi farmakoterapiyi [Antioxidant agents are necessary components of complex pharmacotherapy]. Phytotherapy in Ukraine. 2000; 1: 7-13. (In Ukrainian). 
3. Pylypenko S.V., Tseysler YU.V., Shelyuk O.V. et al. Motorika tolstoy kishki v usloviyakh dlitel'nogo vvedeniya omeprazola i yeye korrektsiya mul'tiprobiotikom [Motility of the colon in conditions of prolonged administration of omeprazole and its correction with a multiprobiotic]. Russian Biopharmaceutical Journal. 2014;6( 2): 37-40. (in Russian).

4. Chevari S., Chaba Y., Sekey I. Rol superoksiddismutazy v okislitelnykh protsessakh kletki i metod opredeleniya yeye v biologicheskikh materialakh [The role of superoxide dismutase in the oxidative processes of a cell and a method for determining it in biological materials]. Laboratory science. 1985; 11: 678-681. (in Russian).

5. Korolyuk M.A. Metod opredeleniya aktivnosti katalazy [Method for determining catalase activity]. Laboratory science. 1988; 1: 16-18. (in Russian).

6. Dubinina Ye.Ye. Rol aktivnikh form kisloroda v kachestve signalnykh molekul v metabolizme tkaney pri sostoyanii okislitelnogo stressa [Role of reactive oxygen species as signaling molecules in tissue metabolism under oxidative stress]. Questions of medical chemistry. 2001; 47(6): 561-581. (in Ukrainian).

7. Yankovskyy D.S., Shyrokobokov V.P., Dyment H.S. Mikrobiom [Microbiome]. FLP Veres 0l. 2017: 640. (in Ukrainian).

8. Hütt P., Andreson H., Kullisaar T. et al. Effects of a synbiotic product on blood antioxidative activity in subjects colonized with Helicobacter pylori. Letters in Applied Microbiology. 2009; 48(6): 797-800. doi: 10.1111/j.1472-765X.2009.02607.x

9. Dvorshchenko K.O., Berehova T.V., Ostapchenko L.I. Vplyv multyprobiotyku «Apibakt ${ }^{\oplus}$ » na perekysne okysnennya lipidiv u pidshlunkoviy zalozi shchuriv za umov tryvaloyi hipoatsydnosti [Effect of «Apibact ${ }^{\otimes}$ " multiprobiotic on lipid peroxidation in the rat pancreas under prolonged hypoacidity]. World of medicine and biology . 2010; 2: 55-57. (in Ukrainian).
Prospects for further research are the study of superoxide dismutase and catalase activity in the mucous membrane of the large intestine in rats under the long-term administration of omeprazole and combined administration of omeprazole and multiprobiotics.

The work is a fragment of the resear project "The role of $T R P V-4$ receptors in regulation of the gastro-intestinal tract", state registration No. 0118 U004306.

\section{ORCID and contributionship:}

Serhii V. Pylypenko: 0000-0002-5537-7679 A, B, E, F

Andrii A. Koval: 0000-0002-8572-7000 A, B, C, D

Viktoria V. Makarchuk: 0000-0002-2325-6776 ${ }^{\text {B,C,D }}$

\section{Conflict of interest:}

The Authors declare no conflict of interest.

\section{CORRESPONDING AUTHOR}

Serhii V. Pylypenko

Ukrainian Poltava V.G. Korolenko

National Pedagogical University

2 0strogradski St., 36000, Poltava, Ukraine

tel: +380951269186

e-mail: pilipenko_s@ukr.net

Received: 24.03 .2020

Accepted: 10.11 .2020

A - Work concept and design, B - Data collection and analysis, C - Responsibility for statistical analysis,

D-Writing the article, $\mathbf{E}$-Critical review, $\mathbf{F}$ - Final approval of the article 